IZA DP No. 9935

Single and Investing:

Homeownership Trends among the Never Married

Kusum Mundra

Ruth Uwaifo Oyelere

May 2016 


\title{
Single and Investing: Homeownership Trends among the Never Married
}

\author{
Kusum Mundra \\ Rutgers University \\ and IZA \\ Ruth Uwaifo Oyelere \\ Morehouse College \\ and IZA
}

Discussion Paper No. 9935

May 2016

IZA

P.O. Box 7240

53072 Bonn

Germany

Phone: +49-228-3894-0

Fax: +49-228-3894-180

E-mail: iza@iza.org

\begin{abstract}
Any opinions expressed here are those of the author(s) and not those of IZA. Research published in this series may include views on policy, but the institute itself takes no institutional policy positions. The IZA research network is committed to the IZA Guiding Principles of Research Integrity.

The Institute for the Study of Labor (IZA) in Bonn is a local and virtual international research center and a place of communication between science, politics and business. IZA is an independent nonprofit organization supported by Deutsche Post Foundation. The center is associated with the University of Bonn and offers a stimulating research environment through its international network, workshops and conferences, data service, project support, research visits and doctoral program. IZA engages in (i) original and internationally competitive research in all fields of labor economics, (ii) development of policy concepts, and (iii) dissemination of research results and concepts to the interested public.
\end{abstract}

IZA Discussion Papers often represent preliminary work and are circulated to encourage discussion. Citation of such a paper should account for its provisional character. A revised version may be available directly from the author. 
IZA Discussion Paper No. 9935

May 2016

\section{ABSTRACT \\ Single and Investing: Homeownership Trends among the Never Married}

In recent years, singles have begun to take on a more prominent role in reshaping America. As a group, singles are increasingly becoming influential in politics and in the determination of many macro socioeconomic outcomes. In this descriptive paper we focus on homeownership among a subset of singles, the never married. In particular we investigate potential differences in the relationship between several homeownership determinants for singles in comparison to the married. In addition, we test for heterogeneity across race and skill level in the gender gap in homeownership and the probability of homeownership before and post the recession. Our results suggest that there are some differences in the relationship between certain factors and homeownership for singles versus those who are married. In particular, we find age, gender, and number of children affect the probability of homeownership differently for singles compared to those who are married. We also find that while on average there is a higher probability of homeownership from 2007 onwards for singles, there are gender, education and racial differences. Our results also suggest significant heterogeneity across race and skill level in homeownership probabilities for singles.

JEL Classification: J10, J11, D10

Keywords: homeownership, single, ethnicity, gender, race, recession

Corresponding author:

Ruth Uwaifo Oyelere

Department of Economics

Morehouse College

830 Westview Drive SW

Atlanta, GA 30314

USA

E-mail: ruth.uwaifo@morehouse.edu 


\section{Introduction}

Two important decisions that shaped American life for young adults in the past were the decision to get married and the decision to own a home. Most people who owned homes in the past were married or once married (divorced or widowed). As family life in America has evolved over time and more people are choosing to stay single, the strong correlation between homeownership and marriage has slowly been attenuated. According to the Pew Research foundation, in $196072.2 \%$ of adults were currently married, but this number has declined to $50.5 \%$ by 2012 . The rising share of single adults in the U.S and the limited knowledge on their home buying decisions and heterogeneity within this population is the motivation for this descriptive paper.

There is a growing trend of buying homes among the single population in the U.S. This trend has been referred to as "Going Solo" according to Klinenberg (2013). In this paper we investigate homeownership among a part of this growing segment of the population-single adults who have never been married. The rationale for our focus on the never married singles versus all singles is that the decision making process about home buying or ownership for a person who lost a spouse or is divorced, may differ significantly from an individual who has never been married even though both can be classified as single.

The extensive literature on homeownership patterns in the U.S. is typically analyzed for married couples or the whole population accounting for marital status. This focus comes as no surprise since the "American Dream" of home buying is more often associated with a household consisting of couples. Hence, there is limited discussion of homeownership among the single population. ${ }^{1}$ The greater focus in homeownership discussions on married households in which males are typically household head, has also inadvertently led to very limited discussion on homeownership by women headed household and hence on the gender homeownership gap.

Another possible reason for limited discussions on the gender homeownership gap in the past

\footnotetext{
${ }^{1}$ For a detailed discussion on the homeownership literature especially in recent years, see Painter et al. 2001; Gabriel and Rosenthal 2005; Mundra 2013; Mundra and Uwaifo Oyelere 2013 to name a few.
} 
literature is the measurement of assets like homeownership at the household level, making it difficult to disentangle asset ownership for men and women who are married. As the married group were a significant portion of the population in the 18-65 demography in the past, investigating heterogeneity across gender in homeownership was not feasible in a small sample analysis. Only recently do we see an increasing trend of singles, especially women, investing in homeownership in the U.S. Some of the possible explanation for this shift among single women are career growth, higher labor force participation and earning power, postponement of marriage decisions and shifts in cultural norms on gender roles and expectation in the U.S. Given this trend, estimating the gender gap in homeownership for singles is potentially insightful.

Within the limited literature that exists on the gender gap in homeownership, Sedo and Kassoudji (2004) show that the gender gap is more pronounced in homeownership rather than in homeownership value or equity. Blaauboer(2010) using Netherland's Kinship Panel show that single women are less likely to own a home compared to men and earning potential for buying homes matters more for men than women. ${ }^{2}$ Gandelman (2008) using individual level data for Chile, Honduras and Nicaragua show that women on an average have a lower probability of owning a home but women who are head of their families, no matter whether they are single, separated or divorced, have higher probabilities of owning homes.

In this paper specifically we investigate three patterns that allow us to better understand homeownership trends for the growing single never married - an increasingly influential sub population. First, we examine what are the determinants of single never married homeownership and how they differ compared to married or divorced households. Since there is an increasing investment in homeownership among the single population, it is important to understand what are the drivers of homeownership for this group and examine how these factors may differ from the factors relevant for the married population.

\footnotetext{
${ }^{2}$ Dowling (1998) uses materials from in-depth, semi-structured interviews with 60 men and women in two neighbourhoods in Vancouver, British Columbia finds that contrary to common expectations homeownership represents both middle-class masculinity and middle-class feminism.
} 
Second, we explore the gender gap in homeownership among singles and how this gap varies across various levels of education and ethnicity. Given there are significant homeownership gaps among various ethnic groups, it is important to highlight how ethnicity affects homeownership outcome for singles. ${ }^{3}$ Education is an important determinant of homeownership and we also analyze whether homeownership increased only among highly skilled educated singles or also for singles with lower levels or education.

Lastly, we want to explore how the Great recession changed the homeownership trajectory for singles. Another related question we focus on is whether more singles were able to enter the housing market during the post recession period and if yes how did this vary based on their education and ethnicity. Increasing, recent literature shows that there was heterogeneity in how the Great recession affected various segments of the U.S. population. For instance some papers have shown that minorities were adversely affected compared to Whites (Allen 2011; Kochar 2009). Whereas, papers looking at immigrant homeownership find that immigrants were not as adversely affected as natives (Kochar 2009; Mundra and Uwaifo-Oyelere 2013). The documented heterogeneity in the effect of the Great recession in the U.S population as a whole forms the basis for why we want to examine how homeownership changed across singles by education/skills and by ethnicity.

To answer these questions we make use of data from the Consumer Population Survey (CPS) over the years 2000-2013. However, we focus most of our attention on the subgroup who are single. Using probit models and controlling for demographic and economic factors that are correlated with homeownership, our results suggest that there are some differences in the relationship between certain factors and homeownership for married versus those who are single. For singles, we find evidence of heterogeneity across race and education in the impact of the recession on the gender homeownership gap. We also find that in general, education and ethnicity are important for homeownership outcomes for singles in the U.S. In particular, we also find that an increase in the likelihood of homeownership for singles in the 2007-2012 period is limited to those with college or

\footnotetext{
${ }^{3}$ For detail homeownership literature across ethnicity see Borjas (2002); Myers and Liu (2005) and Mundra and Uwaifo-Oyelere (2015) to name a few.
} 
advanced degrees. Moreover, within these education groups, the increased likelihood is only noted for Whites, Hispanics, and Black males. For Asians with at least a college education, we do not note any change over time whereas for Black females with advanced degrees we note a decline overtime. Finally, we find that while on average single women are less likely to own homes than single men, differences exist across education level and race. In particular for Blacks and Whites with advanced degrees and Hispanic with college degrees, a negative gender gap exists. This implies that women are more likely to own homes than men. In contrast among single, Whites and Blacks with less than a college degree and among Hispanics with less than a high school education, men are more likely to own a home than women.

Our paper contributes to the literature in two ways. First, it fills an important gap in the homeownership literature by considering a growing group that often receives less attention. In addition, our paper highlights the significant heterogeneity in the homeownership trends across gender, education and race for the never married. Such information is useful for policy makers and practitioners and facilitates accurate targeting.

The rest of the paper is organized as follows. In section 2 we describe the data we are using. In the next section we discuss trends and in section 4 we discuss our empirical method. Section 5 summarizes our results and we conclude in the last section.

\section{Data}

Our sample is derived from the CPS, which is a microdata set that provides detailed information about individuals and households. The CPS is a monthly U.S. household survey conducted jointly by the U.S. Census Bureau and the Bureau of Labor Statistics. We specifically make use of the March CPS which contains the Annual Demographic File and Income Supplement. We derive multi-stage stratified samples of the March CPS from Integrated Public use Microdata Series (IPUMS). IPUMS-CPS is an integrated set of data from 52 years (1962-2014) of the March CPS. However we only make use of data from 2000-2013. Our choice of this period is linked with the 


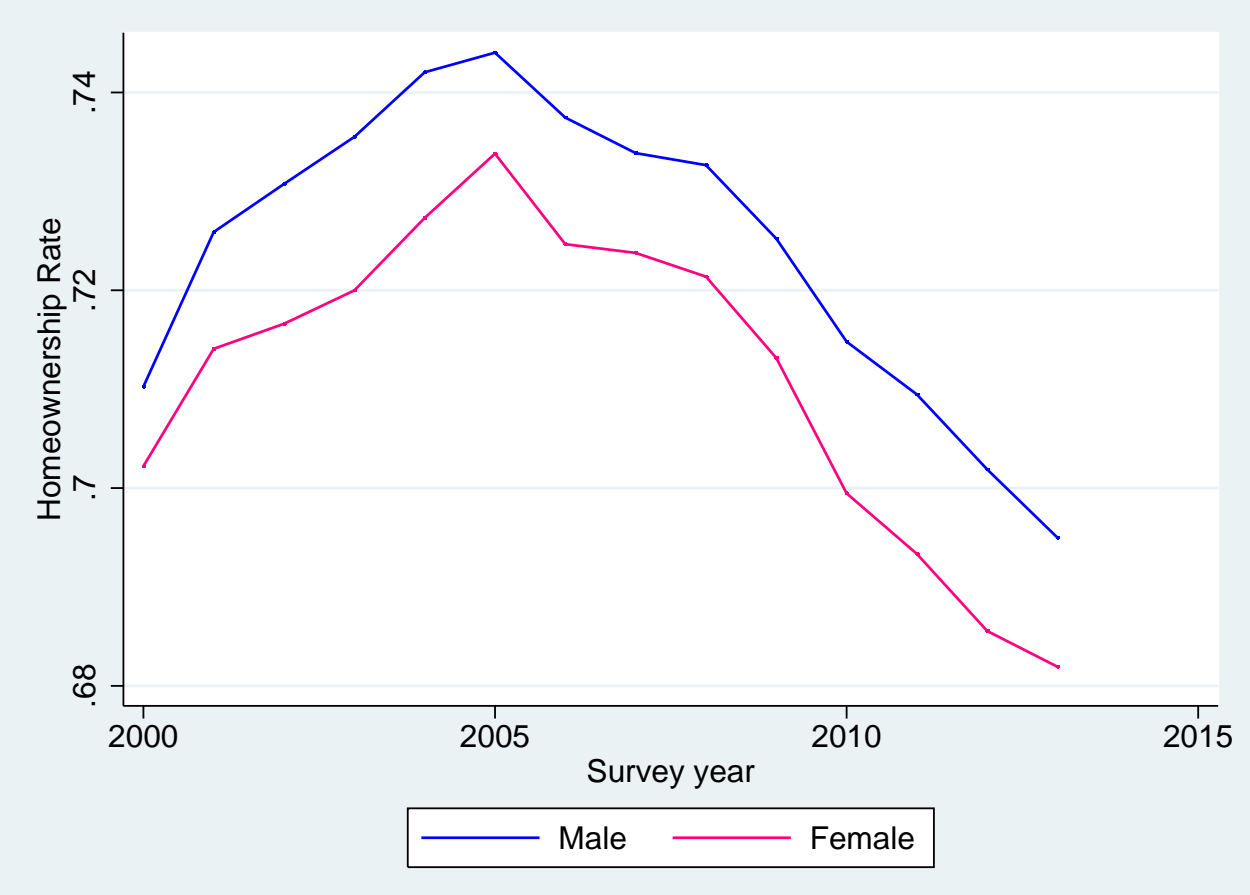

Figure 1: Homeownership Trend 2000-2013

significant increase in singles during the last decade. Moreover, we are also interested in how the recession affects homeownership for singles. Hence the need to restricting our period of analysis to a reasonable expanse of time before and after the recession. ${ }^{4}$

\section{Homeownership Trends -Descriptive Statistics}

Figure one highlights trends in homeownership between 2000 and 2013 for men and women. The graph shows that the proportion of people who own homes was on the rise up until 2005 and has fallen steady during the post recession period. We also observe a small positive gender gap in homeownership with men having a higher rate of homeownership than women over the entire

\footnotetext{
${ }^{4}$ Given all monetary variables in IPUMS CPS are in nominal dollars and we make use of repeated cross sections over time, we adjust all monetary variables used in our analysis to constant 1999 dollars using CPI-U adjustment factor available in IPUMS (which corresponds to the 2000 CPS dollar amounts). Since the CPS makes use of a complex stratification sampling, we include personal weights for individual in our analysis.
} 


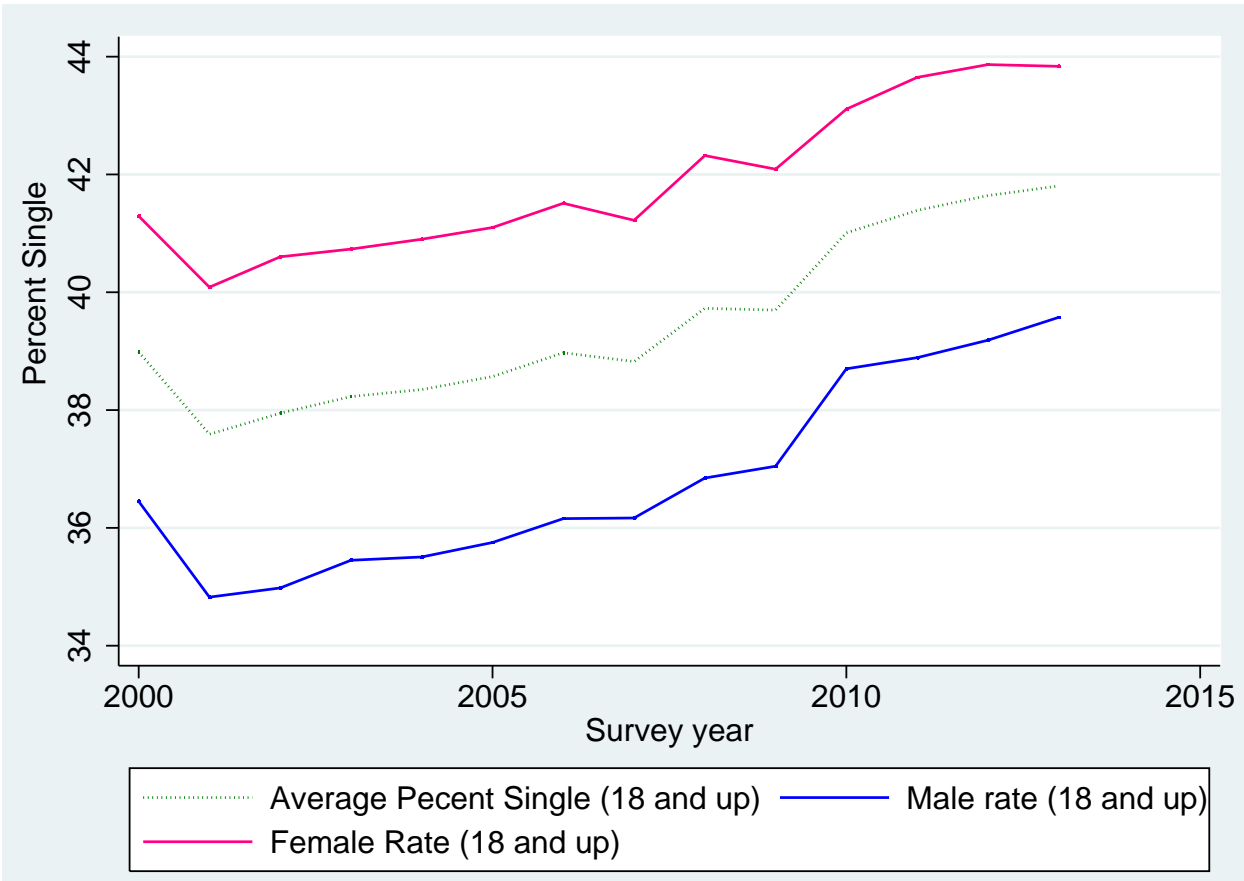

Figure 2: Share Single/Not Married (18 and Up)

period. ${ }^{5}$ The size of this gap reduced towards the recession and has been expanding in the post recession period.

In this paper our focus is on the single population, which has been growing over time. Figure two shows the trends in the single share of the population 18 years and older over time. There are a number of observations we can highlight from this figure. First in every year from 20002013, the percent of single women is higher than single men. In addition, the average share of singles is rising over time and only declined significantly between 2000 and $2001 .{ }^{6}$ Also notice that the trend in percentage single differs slightly between men and women over the period considered with a steady increase in this share for men. In contrast the share of single women experienced other periods of slight decline over time. Another interesting observation is that the percentage of

\footnotetext{
${ }^{5}$ The gap ranges from women homeownership being $0.08 \%-1.6 \%$ lower than men.

${ }^{6} \mathrm{~A}$ possible explanation for the decline in the percentage of people single in 2001 was the "millennium effect" when many people rushed to get married in the year 2000. Given our data uses the march CPS, many of these marriages would have taken place post March in the year 2000 and would only be reflected in the data in 2001.
} 


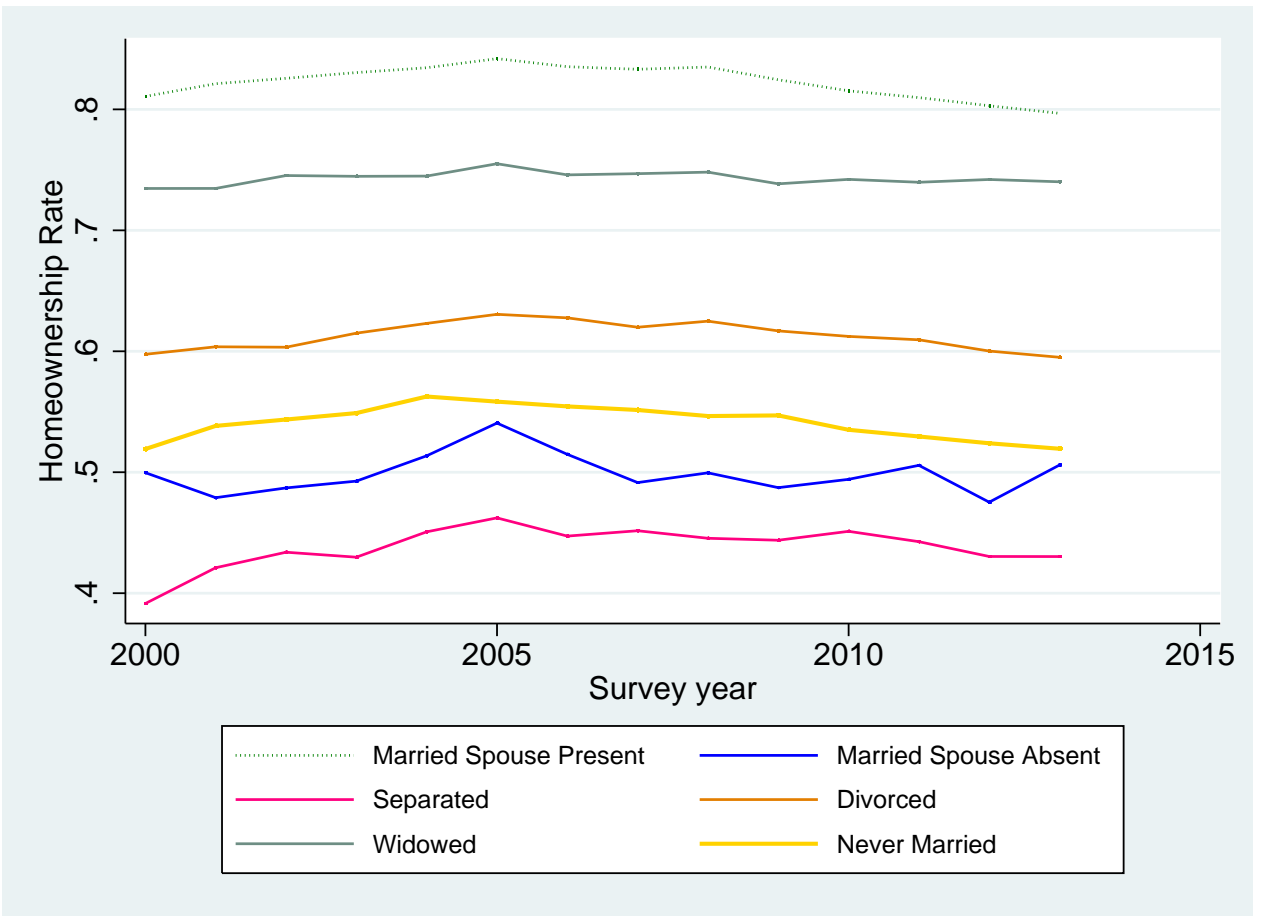

Figure 3: Trends in Homeownership by Marital Status

women who are single has not increased as steeply as men over the 2000-2013 period. Specifically, the share rose from about $40 \%$ of women to $43.9 \%$ over this period. In contrast the share of single men over 18 years rose from $34.8 \%$ to $39.6 \%$. Another interesting observation is that while more women are currently single than men, the single population of men and women exhibit significant heterogeneity. In particular, if we break up the single population into those who are widowed, divorced and never married, we find that while more women are single, a higher proportion of men have never been married. Specifically we find that $26.05 \%$ of men are never married. In contrast only $21.7 \%$ of women have never been married. Differences also exist in the percentage of singles who are divorced by gender. In particular, $8.4 \%$ of men have a current status of divorced compared to $11.44 \%$ for women. This difference suggests that more men who get divorced remarry. Similarly the difference in the proportion of widowed men and women (2.3\% compared to 8.7\%) suggests that compared to women more men who lose their spouses remarry. 
Next we consider homeownership trends over our data period 2000-2013. Figure 3 shows the trends in homeownership by marital status. We make use of the marital status break down constructed in the CPS. ${ }^{7}$ Figure 3 shows that married couple with spouse present have consistently the highest proportion of homeownership over this period. The gap in homeownership for those married with a spouse present and those married with a spouse absent is significant. However, the select nature of certain groups like those who are separated or have an absent spouse explain partly the lower homeownership rates for those groups. Notice that as expected, individual who are married have the highest homeownership rates followed by those who are widowed and divorced. The trend in each of these categories of people with respect to homeownership has also varied over time. While homeownership rates increased for single, divorced and married up until 2005, it have declined subsequently. In contrast, the homeownership rates for widowed has remained the most stable over our evaluation period. For those who are separated, if we compare homeownership rate in 2000 to 2010, on average homeownership rates have increased. This trend is in contrast to other groups for which homeownership rates in 2013 are back to 2000 levels. For those who are married with a spouse present, homeownership rates are slightly lower in 2013 compared to 2000.

We are interested in those who are not married in this paper given the limited research on this growing group. For this group, we examine differences in homeownership across gender over time. In particular for our econometric analysis we focus on a sub-group of the not married- the never married. As mentioned in the introduction the rationale for our focus on the never married single versus all singles is that the decision making process about home buying or ownership for a person who has lost a spouse and is now single or one who got divorced may differ significantly from individuals who have never been married even though they can all be classified as single. Moreover as noted in figure three, homeownership for divorced or widowed is much higher than those who have never been married. In addition, we lack information on when those who are currently divorced or widowed bought their homes. Given the high shares of homeownership for divorced and widowed

\footnotetext{
${ }^{7}$ In the CPS individuals are broken down into married with a spouse present, married with a spouse absent, separated, divorced, never married and widowed.
} 
compared to the never married, it is fair to assume that many of the formerly married acquired their homes while married which may be problematic for the trends we are focused on examining in this paper. The potential issues noted above provide the impetus to exclude the widowed and divorced from our main analysis even though they are currently single. In figure 4 we highlight differences across the divorced and never married by gender. We focus on homeownership trends by gender of never married, divorced and include rates for married as a bench mark. We exclude widowed in this graph to avoid cramming too many trend lines in the figure. ${ }^{8}$ Notice from figure 4 that there is a gender gap in homeownership for both divorced and singles. However, the gap in homeownership across gender for those who have never been married compared to the divorced differ. Specifically, while there is a small gender gap in homeownership across the divorced group, the gap for never married is significantly larger. These marked differences in the trends for divorced versus never married, though both are currently single, highlighted in figure 4 provides further reason why an analysis solely on the never married is warranted.

Next we examine trends across ethnicity for the never married only. The homeownership gap across ethnicity has been documented in the past literature. Our results in figure 5 for singles never married are consistent with the noted trend in homeownership across ethnicity in the general population. In the U.S, Whites have a much high rate of homeownership than Blacks and all other ethnic groups and this trend holds true in the subpopulation who have never been married. Other interesting patterns from figure 5 include the differences in trend across ethnicity. For example, single Black homeownership rate is slightly higher in 2000 than in 2013 (39.9\% versus 39.8\%). In contrast for other ethnic groups, despite a decline in homeownership rates since the recession, 2013 levels are higher than 2000 levels. Figure 5 also suggests heterogeneity in the decline in homeownership for the never married across ethnicity post the recession. In particular, Asians experienced the steepest decline from $54.5 \%$ in 2008 to $45.7 \%$ in 2013 . In contrast, Whites, Blacks and Hispanics experienced decreases of $2.4 \%, 1.3 \%$ and $2.6 \%$ respectively.

\footnotetext{
${ }^{8}$ Moreover, the inference including this group is the same.
} 


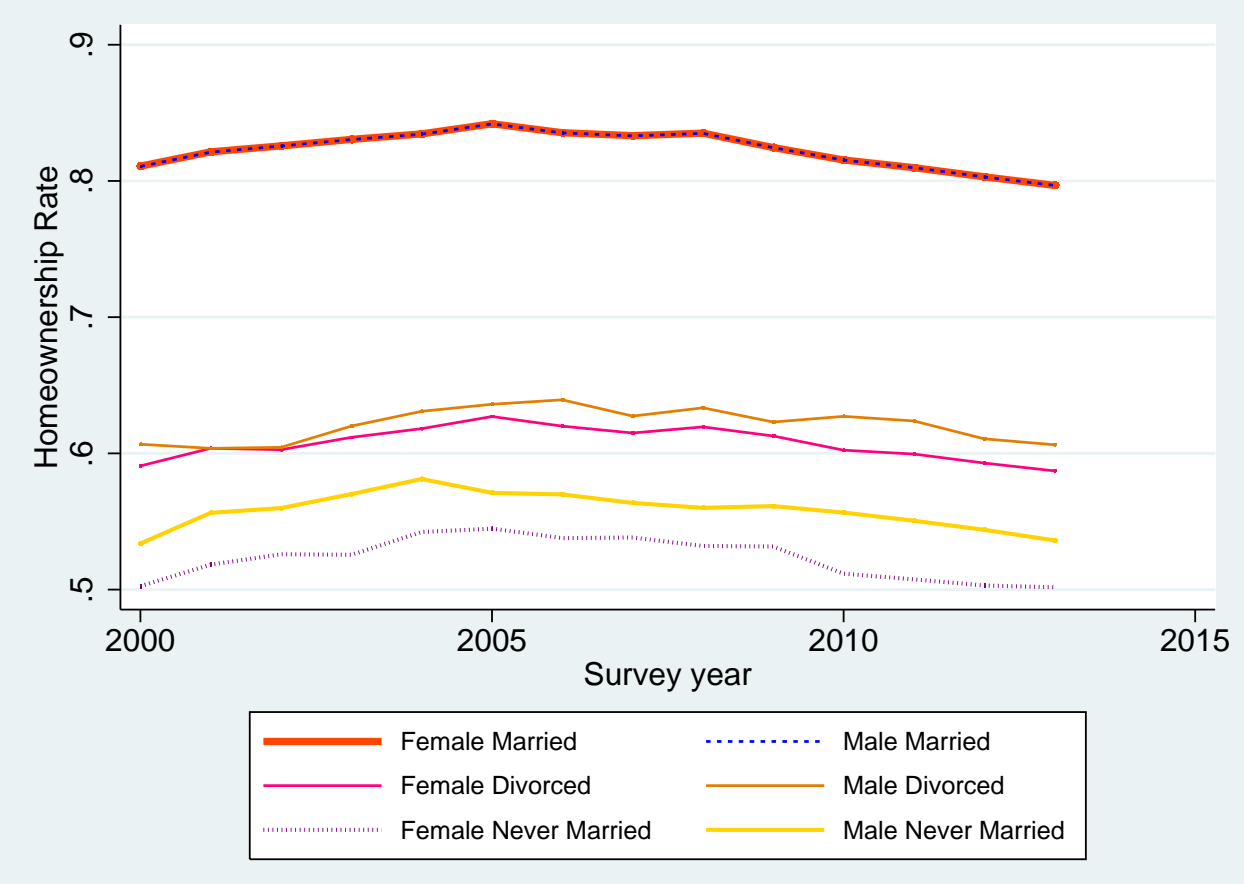

Figure 4: Married, Divorced and Never married Homeownership Trends by Gender 


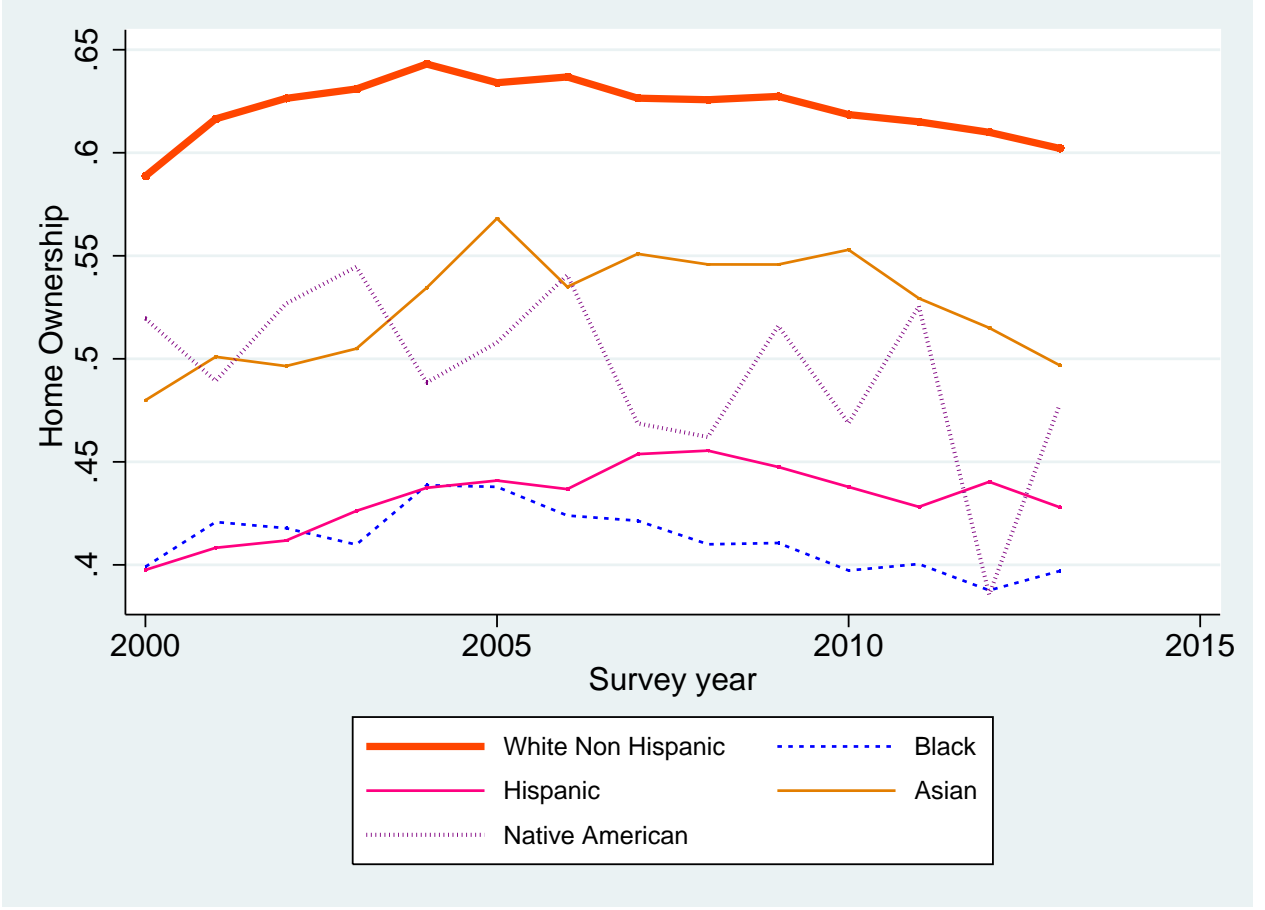

Figure 5: Single Homeownership Trends by Ethnicity 
Another interesting way to consider homeownership across the growing single population is to examine trends across education level. Figure 6 highlights these trends. Notice the gap between singles who have advanced degree and those with lower levels of education. An interesting trend among singles is the higher homeownership rates for those with just high school and some college education compared to those who have college degrees. However, this gap has decreased significantly over time and is linked with the significant increase in homeownership rates among the never married with college degrees before the recession. Keep in mind here that this trend is only noted for never married. On average in the general population, those with a college degree have higher homeownership rates than those with a high school degree. Figure 6 also shows that the recession affected homeownership across each education level however the severity differs across education levels. The largest decline occurred for those with advanced degrees 5.9 percentage points and the lowest decline occurred for those with college degrees 0.4 percentage point. Both those with high school and those with less than high school have lower homeownership rates in 2013 compared to 2000. In contrast, those with college and advanced degrees, although, they experienced a decline during the recession have a higher homeownership rates in 2013 compared to 2000. Another observation from figure 6 is that there was variation in the timing of the decline in homeownership over the 2000-2013 period. Specifically the graph suggests that homeownership rates were declining for those with high school or less than high school education even before the recession. In contrast for those with college and advanced degrees, decline in homeownership rates are observed from 2006 onward.

The descriptive analysis highlighted above suggests that trends for the never married are different from the married. In addition the above trends suggest that for the never married, there is heterogeneity in homeownership across gender, education level and ethnicity. We explore this potential heterogeneity further in a regression model framework. In addition we explore the potential role of the recession in magnifying or attenuating these differences. 


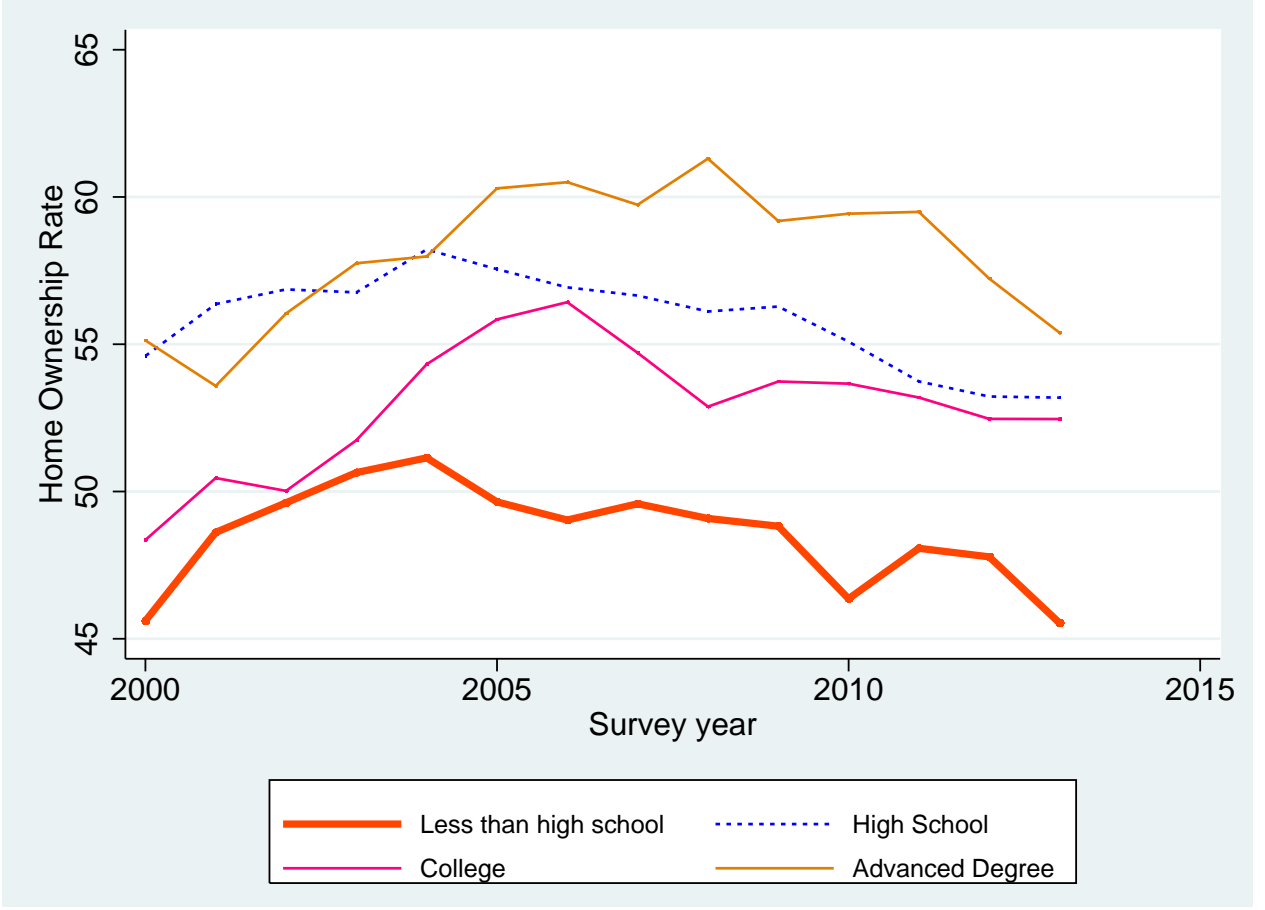

Figure 6: Single Homeownership Trends by Skill 


\section{Empirical Model and Results}

To examine the correlates of homeownership among the never married in the U.S.(henceforth we will refer to never married as single for simplicity), and to explore the heterogeneity across gender, education and ethnic groups, we estimate the following probit model and derive the marginal effects for our variables of interest. Our basic model is as follows:

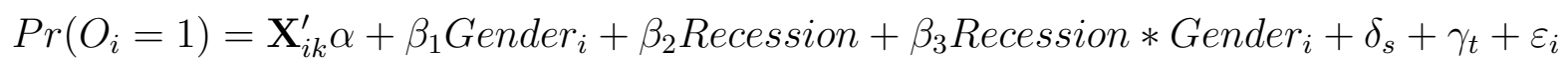

Where $O_{i}$ is the decision to own a home by the individual $i$ and takes the value of 1 if an individual owns a home and 0 otherwise. Vector $X$ captures individual controls that are important in the home buying process or the decision to own a home. The variables included in the vector $X$ include educational attainment, age, income, proxy for savings (interest income), number of children, employment status, ethnicity, and citizenship status. Our ethnic groups are white (Non Hispanic), Black, Hispanic, Asian, Native American, and Mixed Race. ${ }^{9}$ We divide the sample into employed, not in the labor force (NILF), NILF with Disability and unemployed. For citizenship status we include naturalized citizen, not a citizen and native group. Gender is a dummy that takes value 1 for female head of the household and 0 for male. Our recession and after dummy takes value 1 for the years 2007 - 2013 and 0 otherwise. We include total real income of the households and total real interest income in vector $X$ to control for household savings and home buying potential. We convert nominal income and interest rates into real values using the CPI. All our specifications include state fixed effects $\delta$, year fixed effects $\gamma$, and metro area dummies. We report the marginal effects from the probit model.

\footnotetext{
${ }^{9}$ The Hispanic group is restricted to White Hispanic and the Mixed category includes all those who self-identify themselves as mixed race in the CPS.
} 


\section{Results}

Table 1 provides a summary of the results focused on comparing the factors that are important for predicting homeownership by marital status. We summarize the estimated effects derived from the basic model estimated over the whole sample, the married group, the divorced and widowed group, and the singles (never married) group. The reference group for the categorical variables are white (non-Hispanic), unemployed and native born. Column (1) summarizes the results for the regression with the entire sample. As this specification includes the whole sample, we can also control for marital status with dummies for widowed, married with absent spouse, never married, divorce and separated. The reference group for the marital status dummies is married individuals. The estimates on these dummies are not included in Table 1 column (1) to reduce table length but suggest that after controlling for the basic predictors of homeownership, all other groups have a lower probability of homeownership compared to married individuals with spouse present. This is an expected result consistent with the past literature. A more surprising result is that after controlling for factors that predict homeownership, single individuals have the lowest gap in homeownership compared to married with spouse present. Specifically, singles have a $15 \%$ lower likelihood of homeownership than married with spouse present. This regression result is worth noting because it is in contrast to the inference from figure 3 which suggests consistently lower homeownership rates for singles compared to divorced or widowed over the period of observation. Our regression results suggest that in comparison to the group married with spouse present, divorced singles and widowed singles on average have about a $19 \%$ and $26 \%$ respectively, lower probability of homeownership which is larger than the $15 \%$ that is exhibited by the never married group. This difference highlights the importance of controlling for other factors that could potentially affect homeownership. In Column (2)-(4) we estimate our model of interest on sub-samples. Our goal here is to check for heterogeneity across groups in key factors that could affect the probability of homeownership. Column (2) summarizes the results for the model estimated solely on the married sample. In column (3) estimates from the regression on the sample of divorced and widowed are 
captured while in column (4), regression estimates on the sample of singles (never married) are presented. As expected, years of education, age, income and savings significantly increase the probability of homeownership.

For a subset of variables, we compare the estimated coefficients for singles to those of the married group and also the divorced and widow group. We note significant heterogeneity in the direction of the relationship. First, when we consider the whole population there does not appear to be a homeownership gap across gender (column 1). However once we break down the sample into the aforementioned groups, we find that this gap exists. In particular, married women are $3.1 \%$ more likely to own homes than married men. In contrast single women are $2.7 \%$ less likely to own homes than single men. For the divorced and widowed, we find no gender gap. When we consider age, we also note different effects. Age increases the probability of homeownership for the married and divorced/widowed groups. In contrast there is a significant (though small) negative correlation between age and homeownership for singles. Number of children increases the probability of homeownership for those who are married or in the divorced and widowed groups but decreases the probability of homeownership for those who are single even after we have controlled for income. The results in Table 1 also suggest that the likelihood of owning a home increased post recession for both married and single. However, the increase is greater for the never married single group. The interaction variable between recession and gender is insignificant for the single group but is significant for the married group. This finding suggests that across gender, the recession had differential impacts on homeownership probabilities for the married but not the single.

For other variables like income or savings, while the magnitude of the estimated impacts differ across married and single, the difference is negligible in many instances. Other differences across groups in estimated coefficients include education. The results in table 1 suggest that education increases the probability of homeownership for the married compared to the single group by 4 percentage points. Also, the gap in the likelihood of owning a home between the employed and the unemployed is much larger for the married than those who are single (8.2 vs 2.4 percentage 
points more likely). Consistent with past literature on race/ethnicity, we find that Whites are more likely to own homes than all other ethnicity apart from Asians. ${ }^{10}$ For Asians and Whites the relationship is more nuanced. For the married group, Asians are less likely to own a home than Whites. However, when we look at the single group or the divorced/widowed group, Asians have a higher probability of homeownership than Whites. There are also some differences worth noting when we consider immigration status. After controlling for typical predictors of homeownership, we find that across all groups noncitizens have the biggest homeownership gap compared to U.S born. In contrast, for naturalized immigrants, we find those who are married are $1.6 \%$ less likely than native born to own a home. However for naturalized immigrants who are single or the group of widowed and divorced, we do not find any gap in homeownership.

The basic message from Table 1 is that the variables that determines the probability of a single individual owning a home may differ from the factors that are important for married individuals. Moreover, the direction of the relationship between these factors and homeownership can differ for single people compared to married couples. In the remaining part of the paper we focus on the single population, exploring possible heterogeneity in home ownership determinants/correlates by education level and ethnicity.

Table 2 highlights the results for our model for singles across education groups. We divide the single population into four education groups. Those who have less than high school education, high school education, college education, and those with advanced degrees. The results in Table 2 provide insight on the advantages of looking at different slices of the population separately. First, we note that on average, the gender homeownership gap for singles summarized in Table 1 exists only for singles at lower levels of education. Specifically for singles with high school and less, women have significantly lower probabilities of owning a home than men. In contrast single women with an advanced degree have higher homeownership probabilities than their male counterparts. For those with a college degree the results are nuanced. Prior to the recession women had a higher probability

\footnotetext{
${ }^{10}$ Other ethnicities include Black, Hispanic, Mixed or Native American.
} 
of homeownership than men but post the recession men have a slightly higher probability. These results raise an important question as to why single women with advanced degrees are investing in homeownership at a higher rate than similarly educated men controlling for income.

Second, slicing the single population by education level reveals that the higher probability of homeownership post the recession does not apply to all singles. During the recession/post recession period, only those with at least a college degree had higher homeownership probabilities. In contrast those with less than high school degrees were $3.1 \%$ less likely to own a home than before the recession. It is also worth noting that for all groups but those with college education, we do not find any evidence of heterogeneity across gender in the effect of the recession on homeownership. For college educated single women, we find that they improved their homeownership outcome, in the period from the recession onwards, less than men.

Other determinants of homeownership that exhibited significant heterogeneity across education grouping are number of children, naturalized versus native and race. Specifically, while increase in number of children for those who are single reduces the probability of owning a home for those with a college education and less, for those with an advanced degrees, the number of children increases homeownership likelihood. We also find that single naturalized Americans who have a high school education or less are less likely to own a home compared to singles who are native born. However, naturalized Americans with college degrees are more likely to own a home than natives with college degrees. We find no difference for those with advanced degrees.

With respect to race we also note some heterogeneity. In particular single Blacks regardless of their education grouping have a lower probability of homeownership compared to their White counterparts. This is an important result because for all other ethnic groups, education level matters. Single Asians with a college education or less, for example, have a higher probability of homeownership compared with single Whites at similar level. However, single Asians with an advanced degree have a similar homeownership probability as Whites with advanced degrees. Single Hispanics also exhibit heterogeneity across groups. Those with high school education or less have 
a lower probability of homeownership compared to single Whites at a similar level. On the other hand, single Hispanics with a college education or more have a higher probability of homeownership than Whites and the gap is greater for those with advanced degrees. The results for native American and Americans with mixed ethnicity are similar to the extent that singles in these groups with high school or less are less likely than Whites to own a home. For those with at least a college degree, there is no difference in homeownership compared to White Americans.

Next we examine, individually, singles from different ethnic groups. Table 3 presents the results for the 4 major groups. Whites, Blacks, Hispanic and Asian. ${ }^{11}$ Again these results provide some interesting trends. First, the higher probability of homeownership for singles post the recession is only relevant for Whites and Hispanics. However, there are no gender differences in the effect of the recession on homeownership. For Blacks and Asians, there is no difference in homeownership probabilities across both periods Second, the results suggests that for singles, homeownership disparities across gender is only relevant for Whites and Blacks. In both these groups, women have a lower probability of homeownership than men. On an average for single Asians and Hispanics we do not find any gender disparity. We also find that the effect of having more children on homeownership is consistently negative across different racial groups while income has a positive effect on homeownership across all groups. In addition we find that even after we control for education and income, single naturalized Blacks and Asians have higher homeownership probabilities than single native Blacks and Asians. In contrast naturalized Whites and Hispanics have lower homeownership probabilities than native Whites and Hispanics.

The results in Table 3 also suggests that for the single population, education has different effects across race/ethnicity. For single Blacks and Hispanics, higher education levels increases the probability of homeownership. The gap in homeownership probability increases with education. However for single Asians, we find a somewhat inverse relationship. Specifically, the higher the level of education the less likely individuals own homes. Single Asians with advanced degrees are about

\footnotetext{
${ }^{11}$ We do not focus on mixed or Native American given the smaller sample size in the population and for brevity.
} 
11\% less likely to own a home than Asians without a high school education. For single Whites, education level matters far less in homeownership. There is no gap in homeownership for single Whites with less than high school education (base)- compared to those with high school education or an advanced degree. However, those with college education are $6.6 \%$ less likely to own a home than those with less than high school education.

To strengthen our understanding of the factors that are important for homeownership among singles across skill and ethnicity, we also break down the population into sub groups based on both education and ethnicity. In particular, we estimate 16 separate regressions as follows: 4 for Whites, 4 for Blacks, 4 for Hispanics and 4 for Asians. Each of the regressions covers individuals at a particular level of education and ethnicity. In Table 4 Panel A we summarize the main results for Whites, Panel B summarizes the main results for Blacks, Panel C summarizes the main results for Hispanics and Panel D summarizes the results for Asian. Each column captures relevant results for individuals at a particular level of education. Our results suggest significant heterogeneity in homeownership across ethnicity and education levels.

The results in Table 3 suggests than on average only Whites and Hispanic singles had higher homeownership probabilities during the recession and onward (2007-2013). However, when we break these groups down by education level, we find that the increased likelihood of homeownership is restricted to only those with college or advanced degrees for Whites. In contrast for Hispanics, a higher probability of homeownership in the post recession era can be found for those with high school education or higher. For Blacks and Asians despite the fact that Table 3 suggests no change on average in the likelihood of homeownership in the post recession period, we find that among Blacks with advanced degrees, there is a $13.3 \%$ increase in the likelihood of homeownership during this period.

With respect to gender differences, Table 3 suggests both Blacks and White single women have lower homeownership probabilities than men. Table 4, provides a clearer perspective. Among Whites it is single women with high school and less education that have a lower probability of 
homeownership. White single women with advanced degrees have a $6.3 \%$ higher probability of homeownership than White single men. For Blacks we note similar trends as Whites but larger gaps between men and women. Specifically Black single women with high school or less have a much lower probability of homeownership than Black men, $8.5 \%$ and $7.2 \%$ respectively. In contrast, Black single women with advanced degrees have a higher probability of homeownership than Black men. For Hispanics while on average it appears there are no gender differences, women with less than high school have a lower homeownership probability than Hispanic men while single Hispanic women with college education are $6.3 \%$ more likely than Hispanic men to own a home. With respect to Asians, we find that while there are no average differences across gender, women with high school education have lower homeownership probabilities while women with college education have a $6.2 \%$ higher probability of homeownership.

The idea of differential impacts, across gender, of the recession on homeownership probabilities is also explored in Table 4 across skill level and race. While Table 3 suggests no interaction effects for all groups, we find some effects for Blacks, Whites and Asians when we break down each group by education level. Specifically, single White women with less than high school education saw an increase in homeownership in the post recession period compared to single White men. For single Blacks women with advanced degrees we note a significant decrease in the likelihood of homeownership compared to single Black men in the post recession period. In the pre-recession period the gap was 13.3\%. But, during 2007-2013 period the likelihood of homeownership for Black single women with advanced degrees is virtually similar to Black males. We see a somewhat similar pattern among Asians with college degrees. In particular, single Asian women with college degrees experienced a significant decrease in the probability of owning a home in the post recession period compared to single Asian men. In the pre-recession period they had a higher likelihood of owning a home but have a lower likelihood in the 2007-2013 period.

Table 4 reveals three main findings. First in discussing homeownership among a growing segment of the U.S population- singles, race and education are critical. Second, gender plays a role in single's 
homeownership and the effect varies with race. Third, the increase in homeownership for singles in the post recession period does not hold across all ethnicities and is more synonymous with higher levels of education.

\section{Summary, Discussion and Conclusion}

In this descriptive paper, we focus on homeownership among the never married (who we refer to as singles). The never married are a growing population in the U.S and it is useful to highlight the factors that are relevant in their home ownership decisions. In addition, given the relationship between these factors and homeownership can differ for those who are married, divorced, widowed and single, the need to isolate the never married and study them separately is expedient.

We present general trends in the data comparing singles to other groups. Subsequently we examine three questions. First, do the factors that are correlated with homeownership for the married exhibit a similar relationship for those who are single? Second, is there a gender gap in homeownership for singles and does this gap exhibit heterogeneity across race and gender? Finally, are singles more likely to buy homes in recent periods (recession and onward) and is there heterogeneity across race and education level?

Our regression results suggest that there are some differences in the relationship between certain factors and homeownership for married versus those who are single. First, for the married group, women have a higher homeownership probability while for single on average women have a lower probability of homeownership. Second, we find that more children increases the likelihood of homeownership for married but decreases the likelihood for those who are single. More children creates two potential effects- a push and a pull effect. A push effect implies that the more children a person has, the greater the justification for buying a home. Homes are more spacious and typically can house more people than apartments. The pull factor works in the opposite direction. This is because the higher the number of children, the more the substitution of resources away from savings for a home or paying a mortgage to spending on child care and education. Our results 
suggest that for the married the push effect is dominant while for those who are single the pull effect is dominant. A possible reason for this difference is the ability of couples to pool income together which may attenuate the pull factors. Single parents do not have this advantage.

Third, we find that while Whites are more likely to own homes among all ethnic/racial groups for those who are married, among the singles, Asians have the highest likelihood of homeownership even after controlling for education and income. We also note differential effect of age on owning a home. For the married, age increases the probability of homeownership but decreases this probability for those who are single. Culture and norms may have a role to play in this difference. Historically in America, homeownership has been linked with marriage. For many couples the next step after marriage is buying a home. However, the older these individuals are the longer the period they have had to save and the higher the likelihood they have enough savings to buy a home. On the other hand for the single the older they get, their expectations of getting married decreases and if cultural norms link marriage with home buying, then the less likely they are to buy a home. Over the last decade cultural norms have shifted in the U.S. and the link between home buying and marriage has been significantly weakened. Our results suggest a higher likelihood of singles versus married owning homes in recent years compared to pre recession which may be evidence in support of the cultural change and macroeconomic factors alluded to in the above sections.

With respect to our two other questions we find significant heterogeneity across race, gender and ethnicity. For example we find that for singles homeownership outcomes, education and ethnicity are important. Increases in the likelihood of homeownership for singles in recent periods is only on average characteristic of those with college or advanced degrees. Moreover within these education groups, the increased likelihood is only noted for Whites, Hispanics and Black males. For Asians with college education and above we do not note on average any change over time and for Black females we note a decline overtime. Finally, we find that while on average single women are less likely to own homes than single men, that this result is driven for the most part by those with less than college education. Women with advanced degrees who are White or Black are on average 
more likely to own a home than their male counterparts. For Hispanics single females with a college degree, we also find that they are more likely to own a home than their male counterparts.

Our main results raise a few interesting questions. Why is it that women with higher education are making the decision to buy homes at a faster rate than men? Why is this relationship reversed among women with less education ( homeownership likelihood lower for women)? Why does race create differential effects among those with higher education with respect to homeownership? While these questions are beyond the scope of this exploratory descriptive paper, we plan to explore these issues in a future research project. 


\section{References}

[1] Allen, R. 2011. "Who Experiences Foreclosures? The Characteristics of Households Experiencing a Foreclosure in Minneapolis/Minnesota," Housing Studies, 26(6): 845-866.

[2] Borjas, G. 2002. "Homeownership in the immigrant population" Journal of Urban Economics, 52: $448-476$.

[3] Blaauboer, M. 2010. "Family Background, Individual Resources and the Homeownership of Couples and Singles," Housing Studies,25(4),441-461.

[4] Dowling, R. 1998. "Gender, Class and Home Ownership, " Housing Studies, 13(4), 471-486.

[5] Painter, G., Stuart G., Dowell M. 2001. "Race, immigrant status, and housing tenure choice," Journal of Urban Economics, 49, 150-67.

[6] Gabriel, S., Rosenthal S., 2005. "Homeownership in the 1980s and 1990s: aggregate trends and racial gaps," Journal of Urban Economics, 57(1), 101-127.

[7] Gandelman, N. 2009. "Female Headed Households and Homeownership in Latin America" Housing Studies, 24(4): 525-549.

[8] Kochar R., Ana G., Daniel D., 2009. "Through boom and bust: minorities, immigrants and homewonership," Pew Hispanic Report.

[9] Myers, D. and Y. Liu. 2005. "The emerging dominance of immigrants in the US housing market 1970-2000," Urban Policy and Research, 23(3): 347-65; 2005.

[10] Mundra. K. and Uwaifo-Oyelere, R. 2013. "Determinants of Immigrant Homeownership: Examining their Changing Role during the Great Recession and Beyond," IZA Discussion Paper No. 7468 . 
[11] Sedo anad Kossoudji Sedo, S. G. and S. A. Kassoudji 2004. "Room of One's Own: Gender, Race and Home Ownership as Wealth Accumulation in the United States," IZA Discussion Paper No. 1397. 


\section{Table 1: Gender Homeownership Gap and Recession across Marital Status}

\begin{tabular}{|c|c|c|c|c|}
\hline & All & Married & Divorced and Widowed & Never Married \\
\hline & (1) & (2) & $(3)$ & (4) \\
\hline \multirow[t]{2}{*}{ Recession } & $0.016^{* * *}$ & $0.012^{* * *}$ & 0.008 & $0.018^{* * *}$ \\
\hline & $(0.00)$ & $(0.00)$ & $(0.01)$ & $(0.01)$ \\
\hline \multirow[t]{2}{*}{ Female } & 0.000 & $0.031^{* * *}$ & 0.004 & $-0.027^{* * *}$ \\
\hline & $(0.00)$ & $(0.00)$ & $(0.00)$ & $(0.00)$ \\
\hline \multirow[t]{2}{*}{ Recession*gender } & $-0.005^{* * *}$ & $-0.006^{* * *}$ & $-0.008^{*}$ & -0.002 \\
\hline & $(0.00)$ & $(0.00)$ & $(0.00)$ & $(0.00)$ \\
\hline \multirow[t]{2}{*}{ Age } & $0.010^{* * *}$ & $0.022^{* * *}$ & $0.019 * * *$ & $-0.005 * * *$ \\
\hline & $(0.00)$ & $(0.00)$ & $(0.00)$ & $(0.00)$ \\
\hline \multirow[t]{2}{*}{$A g e^{2}$} & $-0.000 * * *$ & $-0.000 * * *$ & $-0.000 * * *$ & $0.000 * * *$ \\
\hline & $(0.00)$ & $(0.00)$ & $(0.00)$ & $(0.00)$ \\
\hline \multirow[t]{2}{*}{ number of children } & $-0.005^{* * *}$ & $0.014^{* * *}$ & $0.024^{* * *}$ & $-0.088^{* * *}$ \\
\hline & $(0.00)$ & $(0.00)$ & $(0.00)$ & $(0.00)$ \\
\hline \multirow[t]{2}{*}{ Real Income Total } & $0.000 * * *$ & $0.000 * * *$ & $0.000 * * *$ & $0.000 * * *$ \\
\hline & $(0.00)$ & $(0.00)$ & $(0.00)$ & $(0.00)$ \\
\hline \multirow[t]{2}{*}{ Real interest Income } & $0.000 * * *$ & $0.000 * * *$ & $0.000 * * *$ & $0.000 * * *$ \\
\hline & $(0.00)$ & $(0.00)$ & $(0.00)$ & $(0.00)$ \\
\hline \multirow[t]{2}{*}{ Yrs of education } & $0.010^{* * *}$ & $0.011^{* * *}$ & $0.011^{* * *}$ & $0.007^{* * *}$ \\
\hline & $(0.00)$ & $(0.00)$ & $(0.00)$ & $(0.00)$ \\
\hline \multirow[t]{2}{*}{ Black } & $-0.139 * * *$ & $-0.160 * * *$ & $-0.114^{* * *}$ & $-0.133^{* * *}$ \\
\hline & $(0.00)$ & $(0.00)$ & $(0.00)$ & $(0.00)$ \\
\hline \multirow[t]{2}{*}{ Hispanic } & $-0.058 * * *$ & $-0.068 * * *$ & $-0.050 * * *$ & $-0.034^{* * *}$ \\
\hline & $(0.00)$ & $(0.00)$ & $(0.00)$ & $(0.00)$ \\
\hline \multirow{2}{*}{ Asian } & $-0.019 * * *$ & $-0.052^{* * *}$ & $0.022^{* * *}$ & $0.023^{* * *}$ \\
\hline & $(0.00)$ & $(0.00)$ & $(0.01)$ & $(0.00)$ \\
\hline Native & $-0.097^{* * *}$ & $-0.101^{* * *}$ & $-0.102^{* * *}$ & $-0.077^{* * *}$ \\
\hline American & $(0.00)$ & $(0.01)$ & $(0.01)$ & $(0.01)$ \\
\hline \multirow[t]{2}{*}{ Mixed } & $-0.074 * * *$ & $-0.083^{* * *}$ & $-0.081 * * *$ & $-0.070 * * *$ \\
\hline & $(0.00)$ & $(0.00)$ & $(0.01)$ & $(0.01)$ \\
\hline \multirow[t]{2}{*}{ Employed } & $0.051 * * *$ & $0.082^{* * *}$ & $0.055^{* * *}$ & $0.024 * * *$ \\
\hline & $(0.00)$ & $(0.00)$ & $(0.01)$ & $(0.00)$ \\
\hline \multirow[t]{2}{*}{ NILF } & $0.081^{* * *}$ & $0.077^{* * *}$ & $0.079 * * *$ & $0.097 * * *$ \\
\hline & $(0.00)$ & $(0.00)$ & $(0.01)$ & $(0.00)$ \\
\hline \multirow[t]{2}{*}{ NILF (cannot work) } & $-0.053^{* * *}$ & $-0.042^{* * *}$ & $-0.082^{* * *}$ & $-0.012^{* *}$ \\
\hline & $(0.00)$ & $(0.00)$ & $(0.01)$ & $(0.01)$ \\
\hline \multirow[t]{2}{*}{ Naturalized } & $-0.017 * * *$ & $-0.016 * * *$ & -0.007 & -0.001 \\
\hline & $(0.00)$ & $(0.00)$ & $(0.00)$ & $(0.00)$ \\
\hline \multirow[t]{2}{*}{ Not a citizen } & $-0.225^{* * *}$ & $-0.174^{* * *}$ & $-0.112^{* * *}$ & $-0.245^{* * *}$ \\
\hline & $(0.00)$ & $(0.00)$ & $(0.01)$ & $(0.00)$ \\
\hline $\mathrm{N}$ & 2011687 & 1217377 & 315765 & 478545 \\
\hline
\end{tabular}

*Note: This table summarizes the marginal effect estimates of a probit model of homeownership. Other variables we control for not shown in the summary above are: Metro area dummies, State and Year fixed effects. In the analysis summarized in column 1 we control for marital status. The reference categories for the summarized dummy variables are white, unemployed and native. ${ }^{*} p<0.05,{ }^{* *} p<0.01,{ }^{* * *} p<0.001$

NILS-Not in Labor Force 
Table 2: Gender Homeownership Gap and Recession for Singles across the Skill Groups controlling for Ethnicity

\begin{tabular}{|c|c|c|c|c|}
\hline & Less than High School & High School & College & Advanced Degree \\
\hline & (1) & $(2)$ & (3) & (4) \\
\hline \multirow[t]{2}{*}{ Recession } & $-0.031^{* *}$ & 0.007 & $0.053^{* * *}$ & $0.078^{* * *}$ \\
\hline & $(0.013)$ & $(0.007)$ & $(0.014)$ & $(0.025)$ \\
\hline \multirow[t]{2}{*}{ gender } & $-0.049 * * *$ & $-0.034^{* * *}$ & $0.015^{* *}$ & $0.068^{* * *}$ \\
\hline & $(0.006)$ & $(0.003)$ & $(0.007)$ & $(0.012)$ \\
\hline \multirow[t]{2}{*}{ Recession*Gender } & 0.013 & -0.006 & $-0.019^{* *}$ & -0.025 \\
\hline & $(0.008)$ & $(0.004)$ & $(0.009)$ & $(0.016)$ \\
\hline \multirow[t]{2}{*}{ Age } & $-0.013^{* * *}$ & $-0.007^{* * *}$ & $0.023^{* * *}$ & $0.039 * * *$ \\
\hline & $(0.001)$ & $(0.001)$ & $(0.001)$ & $(0.002)$ \\
\hline \multirow[t]{2}{*}{ Age Squared } & $0.000 * * *$ & $0.000 * * *$ & $-0.000 * * *$ & $-0.000 * * *$ \\
\hline & $(0.000)$ & $(0.000)$ & $(0.000)$ & $(0.000)$ \\
\hline \multirow[t]{2}{*}{ number of children } & $-0.086^{* * *}$ & $-0.094^{* * *}$ & $-0.015^{* *}$ & $0.022^{*}$ \\
\hline & $(0.003)$ & $(0.002)$ & $(0.006)$ & $(0.012)$ \\
\hline \multirow[t]{2}{*}{ Total Real Income } & $0.000 * * *$ & $0.000 * * *$ & $0.000 * *$ & 0.000 \\
\hline & $(0.000)$ & $(0.000)$ & $(0.000)$ & $(0.000)$ \\
\hline \multirow[t]{2}{*}{ Real Interest Income } & $-0.000^{* * *}$ & $-0.000^{* * *}$ & $0.000 * * *$ & $0.000^{* * *}$ \\
\hline & $(0.000)$ & $(0.000)$ & $(0.000)$ & $(0.000)$ \\
\hline \multirow[t]{2}{*}{ Black } & $-0.217^{* * *}$ & $-0.149 * * *$ & $-0.044^{* * *}$ & $-0.038 * * *$ \\
\hline & $(0.006)$ & $(0.003)$ & $(0.008)$ & $(0.013)$ \\
\hline \multirow[t]{2}{*}{ Hispanic (White) } & $-0.162^{* * *}$ & $-0.024 * * *$ & $0.035^{* * *}$ & $0.068 * * *$ \\
\hline & $(0.006)$ & $(0.004)$ & $(0.009)$ & $(0.016)$ \\
\hline \multirow[t]{2}{*}{ Asian } & $0.026^{*}$ & $0.020 * * *$ & $0.096 * * *$ & -0.000 \\
\hline & $(0.013)$ & $(0.006)$ & $(0.009)$ & $(0.016)$ \\
\hline \multirow[t]{2}{*}{ Native American } & $-0.151^{* * *}$ & $-0.078^{* * *}$ & 0.027 & -0.040 \\
\hline & $(0.013)$ & $(0.010)$ & $(0.033)$ & $(0.055)$ \\
\hline \multirow[t]{2}{*}{ Mixed } & $-0.160 * * *$ & $-0.067 * * *$ & -0.017 & -0.045 \\
\hline & $(0.014)$ & $(0.008)$ & $(0.018)$ & $(0.034)$ \\
\hline \multirow[t]{2}{*}{ Employed } & $0.094^{* * *}$ & $0.026^{* * *}$ & $-0.054^{* * *}$ & -0.003 \\
\hline & $(0.008)$ & $(0.004)$ & $(0.012)$ & $(0.026)$ \\
\hline \multirow[t]{2}{*}{ NILF } & $0.137 * * *$ & $0.099 * * *$ & -0.016 & $0.085^{* * *}$ \\
\hline & $(0.008)$ & $(0.005)$ & $(0.014)$ & $(0.027)$ \\
\hline \multirow[t]{2}{*}{ NILF (cannot work) } & $0.084^{* * *}$ & $-0.018^{* * *}$ & $-0.191^{* * *}$ & $-0.156 * * *$ \\
\hline & $(0.010)$ & $(0.007)$ & $(0.020)$ & $(0.041)$ \\
\hline \multirow[t]{2}{*}{ Naturalized } & -0.012 & $-0.015^{* *}$ & $0.030 * * *$ & 0.012 \\
\hline & $(0.012)$ & $(0.007)$ & $(0.011)$ & $(0.018)$ \\
\hline \multirow[t]{3}{*}{ Not a Citizen } & $-0.213^{* * *}$ & $-0.235^{* * *}$ & $-0.241^{* * *}$ & $-0.307 * * *$ \\
\hline & $(0.006)$ & $(0.004)$ & $(0.010)$ & $(0.015)$ \\
\hline & 91807 & 296896 & 66391 & 23451 \\
\hline
\end{tabular}

*Note: This table summarizes the marginal effect estimates of a probit model of homeownership. Other variables we control for not shown in the summary above are: Metro area dummies, State and Year fixed effects and birth continent dummies. The reference categories are White, unemployed and native. . ${ }^{*} p<0.05, * *$ $p<0.01, * * * p<0.001$ 
Table 3: Gender Homeownership Gap and Recession for Singles across Ethnicity controlling for Skill Level

\begin{tabular}{|c|c|c|c|c|}
\hline & White & Black & White Hispanic & Asian \\
\hline & (1) & (2) & (3) & (4) \\
\hline Recession & $\begin{array}{c}0.021^{* * *} \\
(0.007)\end{array}$ & $\begin{array}{l}-0.014 \\
(0.013)\end{array}$ & $\begin{array}{c}0.055^{* * *} \\
(0.012)\end{array}$ & $\begin{array}{c}0.024 \\
(0.025)\end{array}$ \\
\hline Gender & $\begin{array}{c}-0.017^{* * *} \\
(0.003)\end{array}$ & $\begin{array}{c}-0.064 * * * \\
(0.006)\end{array}$ & $\begin{array}{l}-0.004 \\
(0.006)\end{array}$ & $\begin{array}{c}0.006 \\
(0.011)\end{array}$ \\
\hline Recession*Gender & $\begin{array}{l}-0.001 \\
(0.005)\end{array}$ & $\begin{array}{c}0.005 \\
(0.008)\end{array}$ & $\begin{array}{l}-0.008 \\
(0.008)\end{array}$ & $\begin{array}{l}-0.024 \\
(0.015)\end{array}$ \\
\hline Age & $\begin{array}{c}-0.003^{* * *} \\
(0.001)\end{array}$ & $\begin{array}{c}-0.005^{* * *} * \\
(0.001)\end{array}$ & $\begin{array}{c}-0.005^{* * * *} \\
(0.001)\end{array}$ & $\begin{array}{c}-0.008^{* * *} * \\
(0.002)\end{array}$ \\
\hline Age Square & $\begin{array}{c}0.000^{* * *} * \\
(0.000)\end{array}$ & $\begin{array}{c}0.000^{* * *} \\
(0.000)\end{array}$ & $\begin{array}{c}0.000^{* * *} * \\
(0.000)\end{array}$ & $\begin{array}{c}0.000 * * * \\
(0.000)\end{array}$ \\
\hline Number of Children & $\begin{array}{c}-0.102^{* * *} \\
(0.003)\end{array}$ & $\begin{array}{c}-0.087^{* * *} \\
(0.003)\end{array}$ & $\begin{array}{c}-0.066^{* * *} \\
(0.003)\end{array}$ & $\begin{array}{c}-0.077^{* * *} \\
(0.010)\end{array}$ \\
\hline Total Real Income & $\begin{array}{c}0.000 * * * \\
(0.000)\end{array}$ & $\begin{array}{c}0.000 * * * \\
(0.000)\end{array}$ & $\begin{array}{l}0.000^{*} \\
(0.000)\end{array}$ & $\begin{array}{c}0.000 * * \\
(0.000)\end{array}$ \\
\hline Real Interest Income & $\begin{array}{c}0.000^{* * * *} \\
(0.000)\end{array}$ & $\begin{array}{c}0.000^{* * *} \\
(0.000)\end{array}$ & $\begin{array}{c}0.000^{* *} \\
(0.000)\end{array}$ & $\begin{array}{l}-0.000 \\
(0.000)\end{array}$ \\
\hline High School & $\begin{array}{l}-0.003 \\
(0.004)\end{array}$ & $\begin{array}{c}0.091^{* * *} \\
(0.005)\end{array}$ & $\begin{array}{c}0.106^{* * *} \\
(0.005)\end{array}$ & $\begin{array}{c}-0.031^{* *} \\
(0.013)\end{array}$ \\
\hline College & $\begin{array}{c}-0.066^{* * *} \\
(0.005)\end{array}$ & $\begin{array}{c}0.153^{* * *} \\
(0.009)\end{array}$ & $\begin{array}{c}0.109^{* * *} \\
(0.009)\end{array}$ & $\begin{array}{c}-0.048^{* * *} \\
(0.015)\end{array}$ \\
\hline Advanced & $\begin{array}{l}-0.004 \\
(0.006)\end{array}$ & $\begin{array}{c}0.225^{* * *} * \\
(0.012)\end{array}$ & $\begin{array}{c}0.191^{* * *} * \\
(0.015)\end{array}$ & $\begin{array}{c}-0.109 * * * \\
(0.018)\end{array}$ \\
\hline Employed & $\begin{array}{c}0.016^{* * *} \\
(0.005)\end{array}$ & $\begin{array}{c}0.039 * * * \\
(0.007)\end{array}$ & $\begin{array}{c}0.029 * * * \\
(0.008)\end{array}$ & $\begin{array}{c}0.023 \\
(0.018)\end{array}$ \\
\hline NILF & $\begin{array}{c}0.108^{* * *} \\
(0.005)\end{array}$ & $\begin{array}{c}0.093^{* * *} \\
(0.008)\end{array}$ & $\begin{array}{c}0.085^{* * *} \\
(0.009)\end{array}$ & $\begin{array}{c}0.041^{* *} \\
(0.019)\end{array}$ \\
\hline NILF (cannot work) & $\begin{array}{c}-0.052^{* * *} \\
(0.007)\end{array}$ & $\begin{array}{l}0.017^{*} \\
(0.009)\end{array}$ & $\begin{array}{c}0.040^{* * *} \\
(0.013)\end{array}$ & $\begin{array}{l}-0.014 \\
(0.032)\end{array}$ \\
\hline Naturalized & $\begin{array}{c}-0.025^{* *} \\
(0.011)\end{array}$ & $\begin{array}{c}0.047^{* * *} \\
(0.012)\end{array}$ & $\begin{array}{c}-0.030 * * * \\
(0.008)\end{array}$ & $\begin{array}{c}0.034^{* * *} \\
(0.010)\end{array}$ \\
\hline Not a citizen & $\begin{array}{c}-0.220 * * * \\
(0.009)\end{array}$ & $\begin{array}{c}-0.152^{* * *} \\
(0.008)\end{array}$ & $\begin{array}{c}-0.226^{* * *} \\
(0.004)\end{array}$ & $\begin{array}{c}-0.259 * * * \\
(0.008)\end{array}$ \\
\hline $\mathrm{N}$ & 261884 & 86804 & 82106 & 27753 \\
\hline
\end{tabular}

* Note: This table summarizes the marginal effect estimates of a probit model of homeownership. Other variables we control for not shown in the summary above are: Metro area dummies, State and Year fixed effects. The reference categories are less than high school, unemployed and native. ${ }^{*} p<0.05, * * p<0.01, * * *$ $p<0.001$ 
Table 4: Gender Homeownership Gap and Recession for Singles across Ethnicity controlling for Skill Level

\begin{tabular}{|c|c|c|c|c|}
\hline & $\begin{array}{l}\text { Less than High School } \\
\text { (1) }\end{array}$ & $\begin{array}{l}\text { High School } \\
\qquad(2) \\
\end{array}$ & $\begin{array}{c}\text { College } \\
(3) \\
\end{array}$ & $\begin{array}{c}\text { Advanced Degree } \\
(4)\end{array}$ \\
\hline & \multicolumn{4}{|c|}{ Panel A: White } \\
\hline Recession & $\begin{array}{c}0.003 \\
(0.019)\end{array}$ & $\begin{array}{c}0.007 \\
(0.008)\end{array}$ & $\begin{array}{c}0.070^{* * *} \\
(0.017)\end{array}$ & $\begin{array}{l}0.052^{*} \\
(0.029)\end{array}$ \\
\hline Gender & $\begin{array}{c}-0.053^{* * *} \\
(0.009)\end{array}$ & $\begin{array}{c}-0.029 * * * \\
(0.004)\end{array}$ & $\begin{array}{c}0.009 \\
(0.008)\end{array}$ & $\begin{array}{c}0.061^{* * *} \\
(0.014)\end{array}$ \\
\hline Recession*Gender & $\begin{array}{c}0.027^{* *} \\
(0.013) \\
\end{array}$ & $\begin{array}{l}-0.004 \\
(0.006) \\
\end{array}$ & $\begin{array}{l}-0.013 \\
(0.012) \\
\end{array}$ & $\begin{array}{l}-0.016 \\
(0.020) \\
\end{array}$ \\
\hline & \multicolumn{4}{|c|}{ Panel B: Black } \\
\hline Recession & $\begin{array}{l}-0.015 \\
(0.026)\end{array}$ & $\begin{array}{l}-0.021 \\
(0.016)\end{array}$ & $\begin{array}{c}0.043 \\
(0.043)\end{array}$ & $\begin{array}{l}0.133^{*} \\
(0.076)\end{array}$ \\
\hline Gender & $\begin{array}{c}-0.085^{* * *} \\
(0.011)\end{array}$ & $\begin{array}{c}-0.072^{* * *} \\
(0.007)\end{array}$ & $\begin{array}{c}0.001 \\
(0.019)\end{array}$ & $\begin{array}{c}0.155^{* * * *} \\
(0.036)\end{array}$ \\
\hline Recession*Gender & $\begin{array}{c}0.015 \\
(0.017)\end{array}$ & $\begin{array}{c}0.003 \\
(0.010)\end{array}$ & $\begin{array}{l}-0.009 \\
(0.027)\end{array}$ & $\begin{array}{c}-0.152^{* * * *} \\
(0.049)\end{array}$ \\
\hline & \multicolumn{4}{|c|}{ Panel B: Hispanic } \\
\hline Recession & $\begin{array}{c}0.002 \\
(0.019)\end{array}$ & $\begin{array}{c}0.060 * * * \\
(0.017)\end{array}$ & $\begin{array}{c}0.104^{* *} \\
(0.050)\end{array}$ & $\begin{array}{c}0.266^{* * *} \\
(0.088)\end{array}$ \\
\hline Gender & $\begin{array}{c}-0.020^{* *} \\
(0.009)\end{array}$ & $\begin{array}{l}-0.005 \\
(0.008)\end{array}$ & $\begin{array}{c}0.063 * * * \\
(0.022)\end{array}$ & $\begin{array}{c}0.052 \\
(0.045)\end{array}$ \\
\hline Recession*Gender & $\begin{array}{c}0.002 \\
(0.013)\end{array}$ & $\begin{array}{l}-0.017 \\
(0.011)\end{array}$ & $\begin{array}{l}-0.025 \\
(0.031)\end{array}$ & $\begin{array}{l}-0.003 \\
(0.060)\end{array}$ \\
\hline & \multicolumn{4}{|c|}{ Panel D: Asian } \\
\hline Recession & $\begin{array}{l}-0.083 \\
(0.074)\end{array}$ & $\begin{array}{c}0.048 \\
(0.033)\end{array}$ & $\begin{array}{c}0.051 \\
(0.049)\end{array}$ & $\begin{array}{c}0.131 \\
(0.080)\end{array}$ \\
\hline Gender & $\begin{array}{l}-0.022 \\
(0.034)\end{array}$ & $\begin{array}{c}-0.030^{* *} \\
(0.015)\end{array}$ & $\begin{array}{c}0.062^{* * *} \\
(0.022)\end{array}$ & $\begin{array}{c}0.034 \\
(0.036)\end{array}$ \\
\hline Recession*Gender & $\begin{array}{l}-0.026 \\
(0.047)\end{array}$ & $\begin{array}{c}0.001 \\
(0.020)\end{array}$ & $\begin{array}{c}-0.097^{* * *} \\
(0.029)\end{array}$ & $\begin{array}{c}0.019 \\
(0.048)\end{array}$ \\
\hline
\end{tabular}

* Note: This table summarizes the marginal effect estimates of 16 probit models of homeownership. We control for income, savings, employment status, number of children, age, age square, Metro area dummies, State and Year fixed effects.

Recession refers to the 2008-2013 period. ${ }^{*} p<0.05,{ }^{* *} p<0.01,{ }^{* * *} p<0.001$ 